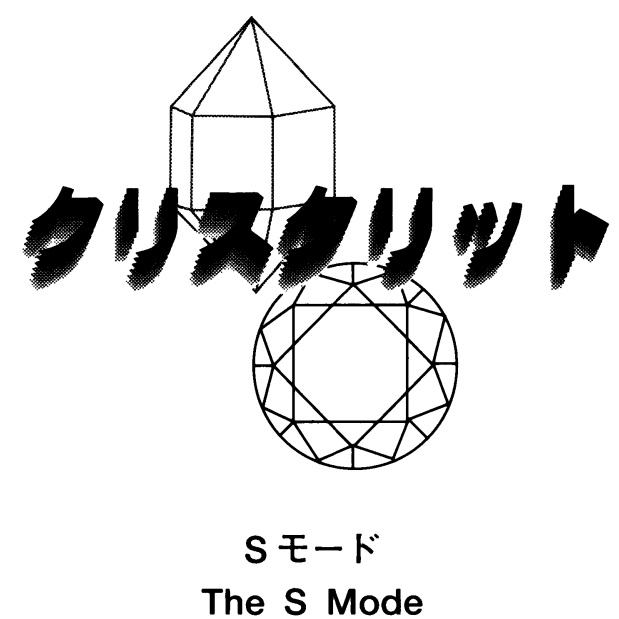

高分子の振動スペクトルの低振動数領域 $\left(\sim 200 \mathrm{~cm}^{-1}\right.$ 以下)には，高分子全体が形を変える動き(鎖全体の伸び 縮みなど）に対応した振動が観測される。例えば，ポリ エチレンの LAM (longitudinal acoustic mode) がよく知ら れている。DNAのラマンスペクトルにおいては，30 $100 \mathrm{~cm}^{-1}$ 領域の線幅がブロードな数本のピークとともに, 線幅が比較的狭く, ラマン散乱強度が強い特徵的な振動乇 ードが $20 \mathrm{~cm}^{-1}$ 前後に最低振動数ピークとして観測され， the lowest-frequency mode, the lowest sharp mode, the $\mathrm{S}$ mode などと呼ばれている。B-DNA（相対湿度 $93 \%$ )では $21 \mathrm{~cm}^{-1}$, A-DNA (相対湿度 $75 \%$ ) では $25 \mathrm{~cm}^{-1}$ と構造転 移に伴い振動数にシフトがみられることから,その起源に 興味がもたれ，振動数の含水量およびカチオン依存性の解 析やモデル計算などが行われてきているが，DNAのどの ような動きに対応しているかについての明確な結論は出 ていない。同様のピークは, RNAやオリゴヌクレオチド の結晶などにおいても報告されている。

(北里大学理学部 菅原洋子)

\section{FLAPW 計算}

\section{Full-potential Linearized Augmented Plane Wave (FLAPW) Calculations}

第一原理計算手法の1つである,フルポテンシャル線形 化 APW バンド計算法である。この方法では価電子のみで はなく内殻電子の波動関数も計算し, 基底状態においては 最も精度の高い方法の1つであるといわれている. 方程式 を解く際の波動関数は, 原子の周りをマフィンティン球と 呼ばれる球を仮定し，その球内領域では球面波展開を，球 外領域では平面波展開を行い, 境界部分で接続することに よって単位胞全体を展開する。また，ポテンシャルには， 密度汎関数理論に基づく局所密度近似の適用により, 精度 の高い電子状態の計算が可能である。この方法では, バル ク結晶の電子状態を結晶の周期性を利用して計算するた め, 全エネルギーの精度が高くなる。この方法により結晶 中の電子状態密度, 電子密度分布, 結晶構造因子など計算 が可能となる.

(産業技術総合研究所 高橋靖彦)

\section{DV-X $\alpha$ 法}

Discrete Variational (DV) $-X \propto$ Method

第一原理分子軌道計算方法の1つであり，分子の電子状 態を得るときに用いられる. 波動関数はそれぞれの原子の 原子軌道の重ね合わせにより分子軌道を形成させる LCAO法に基づき与えられる。 また，ポテンシャルにX $\alpha$ ポテンシャルを用いることにより, 計算速度が速くなって いる.この方法ではモデルクラスターを仮定して計算する ため，小さい分子についての計算精度が高い．また基底状 態のみではなく励起状態を取り扱うことが可能である。こ の方法の特徵として, 原子軌道を考えているために, 電子 状態密度, 電子密度分布に加え, それぞれの原子について 有効電荷, 有効共有結合電荷の值を定量的に導き出すこと が可能となり，化学結合の詳細を検討するのに有用な情報 を得ることができる。（産業技術総合研究所 高橋靖彦)

\section{アラニンスキャン \\ Alanine Scan}

アラニンスキャンは, タンパク質の特定部位のアミノ酸 配列を，遺伝子操作技術によって，アラニンに置換する部 位指定变異導入法である。こうして得られた变異体をin vitro 系あるいはin vivoで機能解析することにより，活性 部位や基質との相互作用に直接関与するアミノ酸残基が 明らかになる.アラニンは，グリシンを除くアミノ酸の中 でもっと小さい側鎖 (メチル基)をもち，タンパク質の親 水性拉よび疎水性領域のどちらにも存在する。 そのため, アラニンへの置換は立体障害や静電反発が少なく, 変異体 の主鎖の構造は野生型と同様であることが多い.アラニン スキャンは，正確に活性部位などを明らかにするが，膨大 な数の变異体を必要とし解析が容易でないことがある. そ こで，X 線結晶構造解析や NMR 法によって決定された夕 ンパク質の立体構造をもとに, あらかじめアラニンスキャ ンを行うアミノ酸残基を選択することで, 効率よく活性に 重要な残基を同定することができる.

(理化学研究所ゲノム科学総合研究センター・

東京大学大学院理学系研究科 香川 亘)

\section{Unison- $\mathbf{X}_{1}$}

$\mathrm{In}_{2} \mathrm{O}_{3}-\mathrm{TiO}_{2}-A_{2} \mathrm{O}_{3}$ 系内の擬二元系 $\operatorname{In} A \mathrm{O}_{3}-\mathrm{In}_{2} \mathrm{Ti}_{2} \mathrm{O}_{7}$ に $\operatorname{In} A_{1-\mathrm{x}} \mathrm{Ti}_{\mathrm{x}} \mathrm{O}_{3+\mathrm{x} / 2}$ と表すことができる層状化合物が存在する $(A ： \mathrm{Al}, \mathrm{Fe}, \mathrm{Ga}, \mathrm{Mn})$. x が小さい場合には斜方晶系を, 大きい場合には単斜晶系をとる。また, $\mathrm{In}_{2} \mathrm{O}_{3}-\mathrm{TiO}_{2}-\mathrm{BO}$ 系 にも単斜晶系をとる層状化合物が存在する $(B: \mathrm{Mg}, \mathrm{Mn}$, $\mathrm{Co}, \mathrm{Ni}, \mathrm{Cu}, \mathrm{Zn}$ ). ソノラ大学 (Universidad de Sonora)に おいて発見されたこれらの化合物群を総称して Unison-X と呼ぶ. いずれも $a$ および $c$ 軸は共通で $b$ 軸方向の基本周 期が異なる 2 つ部分構造からなる複合結晶である. $b$ 軸 
の比は組成に対応して变化し, $b_{1} *: b_{2}{ }^{*}=3: 4$ の整合相 となる場合もあるが一般には不整合な関係にある。なお， In を希土類元素で置換した化合物も Unison-X $X_{1}$ と類似の 構造をとる. (漢陽大学校セラミック素材研究所 硬塚 昇)

\section{複合結晶 Composite Crystal}

少なくとも一方向について異なる基本周期をもってい る複数の部分構造が1つの結晶中に共存したものを複令 結晶と呼ぶ. 通常, 各部分構造ではほかの部分構造との相 互作用による変調が生じており，回折パターンには各々の 部分構造に対応した複数組の主反射に加え, 变調によるサ テライト反射か観測されるのが一般的である. 各部分構造 の基本周期が互いに不整合な関倸のものがある場合は： 次元的な周期性をもたず，その回折点は通常の結晶のよう に 3 本の基本べクトルで指数付けすることはできない。こ れまでに層状，カラム状など，種々の複合結晶が知られて いる. 複合結晶の構造を解く乎段としては超空間群を利用 した解析方法が確立さ机ている。すすなわち, 四次元以上の 高次元空間において仮想的な周期構造を考え, その断面と して周期性のない現実の 次元構造が記述される.

(物質・材料研究機構物質研究所 道卜争・)

\section{低温真空 X 線カメラ}

\section{Low-Temperature Vacuum X-ray Camera}

$90 \mathrm{~K}$ 以下でもバックグラウンドが小さく $\mathrm{S} / \mathrm{N}$ 比が高い $\mathrm{X}$ 線回折像を撮影することにより，高精度な結晶構造解析 が容易に実行できることを目指して開発した. 極低温での $\mathrm{X}$ 線回折実験では,ヘリウムクライオスタットの真空断熱 用の空材からのX 線散乱や真空槽内の結晶試料が直接観 察できないことが大きな障害になっていた。このため,ク ライオスタットの真空槽内に二次元検出器のイメージン グプレートを納め, $\mathrm{X}$ 線入射空と結晶試料および二次元検 出器の間にX 線散乱体をすべてなくすことを考えた。こ れにより（1）結晶試料を $20 \mathrm{~K}$ 程度まで冷却できる，(2) 二次元回折像を高い $\mathrm{S} / \mathrm{N}$ 比で測定できる，(3) 結晶試料を 外から直接観察できて試料のセンタリングが容易である, （4）反射強度を連続的に測定できる低温真空 X 線カメラ の開発に成功した. 本装置は, 単結晶 $\mathrm{X}$ 線回折法による光 励起分子の構造解析を目的として, 科学技術振興事業付の CREST (代表大橋裕二東工大教授) の経費で製作し, SPring-8 BL02B1に設置して一般利用に供している. 詳 細については, SPring-8 利用者情報 Vol.8, No.1, pp.25-31 (2003) を参照さ机たい.

(姫路工業大学理学研究科 鳥海幸四郎)

\section{大振幅振動 \\ Large Amplitude Vibrational Motion}

原子の振動に関するポテンシャル曲面がなだらかな場 合，原子小は低い振動数で大きな振幅で振動する. 代表的な

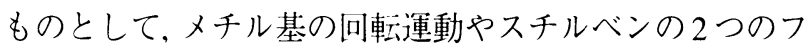
エニル基が逆位相で回転する連動などがある. 分光学的な 研究が多いが、小川らの結晶解析法を用いたスチルベンの 大振幅振動に関する研究 (J. Harada and K. Ogawa: J. Am. Chem. Soc. 123, 10884 (2001)) もある. 大振幅振動 のポテンシャルは, 調和振動子よりは $\sin$ 関数などで近似 される. 分子内あるいは分子間のエネルギー移動や化学反 応などのダイナミックスに大きな役割をはたしていると 考えられている。 (姫路上業大学理学研究科 鳥海幸四郎)

\section{パイエルス歪み \\ Peierls Distortion}

一次元金属では，伝導電子のフェルミ準位の波数 $k_{\mathrm{F}}$ の 2 倍の波数をもつ周期的な格子歪みに対して結晶は不安 定である (パイエルス不安定性)，すなわち，波数 $2 k_{\mathrm{F}}$ の周 期をもつ格子歪みを結晶に与えるとフェルミ準位の位置 に禁制带が生じて電子エネルギーが減少する。次元系で は,この電子エネルギーの減少は格子歪みに伴う弾性エネ ルギーの増大をつねに上回るため, 低温では自発的に格子 が歪み金属一半尊体転移が起こる.この格子歪みはパイエ ルス歪みと呼ばれ, TTF-TCNQ などの擬一次元電子系の 低温相で見られる。..次元 MMX 錯体も擬一次元電子系と 考えられ, パイエルス歪みは架橋ハロゲンの原子位置のシ フトとして現れる。電子相関が大きくない場合, 平均原子 価状態では架橋ハロゲンは複核金属ユニットの中央の位 置を占めるが, パイエルス不安定牲のために混合原子価状 態へ転移して架橋ハロゲンは一方の金属原子の方へシフ トする。 (姫路工業大学理学研究科 鳥海幸四郎)

\section{格子定数計算 \\ Calculation of Lattice Parameters}

単位格子の大きさと形は 3 軸 $(\mathrm{a}, \mathrm{b}, \mathrm{c})$ の長さと軸間の 角度 $(\alpha, \beta, \gamma)$ で示されこの6つの值を格子定数と言う. 格 子定数を求めるにはX 線や電子線を用いた回折実験を行 い回折角を測定し原子面間隔の值を得る. 原子面間隔は格 子定数と面の指数とで示すことができるので 1 つの回折 線から格子定数を未知数とした1つの方程式をつくるこ とができる. 未知数の数だけ回折実験を行い方程式をつく り連立させて解くと格子定数を求めることができるが, 通 常は未知数の 3 倍程度の数の方程式から最小二乗法にて 格子定数を求める.

(北海道大学理学研究科地球惑星科学専攻 三浦裕行) 


\section{最小二乗法 \\ Method of Least Squares}

未知パラメータの值を知るために, 観測值を最もよく説 明できるバラメータが正しいものであると仮定して, 観測 值とパラメータから求めた計算值との差の二乗和が最も 小さくなるようにパラメー夕を決定する方法. 格子定数の
計算においては, 測定した原子面間隔の逆数と格子定数か ら計算した原子面間隔の逆数の差の二乗和が最も小さく なるように格子定数を決定する. 結晶構造の精密化におい ては測定した構造因子と原子座標や温度因子などから計 算した構造因子の差の二乗和が最も小さくなるように原

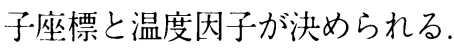

(北海道大学理学研究科地球惑星科学専攻 三浦裕行)

\section{新刊紹介}

\section{準結晶の不思議な構造 ーアルスの森を散歩してー}

平賀贒二 著

アグネ技術センター, 定価 (本体 2.400 円十税)，180 頁 ISBN 4-901496-03-4

アルスとは, 産業革命以前の芸術 (アート) と科学 (サイ エンス)がまだ一体であったころのものを指す言葉だそう である. 準結晶という，5回回転対称の回折パ夕ーンを示 す物質の構造には, 黄金比という誰をも引き付けてやま ない無理数が関係している。この黄金比に関係した美し い性質はかつてのアルスの片鱗を坦間見せてくれる。

本書は準結晶の発見当初から, その構造研究において, 主に電子顕微鏡法を手法として数多くの重要な成果を残 してきた著者による準結晶構造の解説書である. 準結晶 が発見されて約 20 年が経ったが, その構造を理解するた めの基本的な考方方を, 具体的な例を用いてまとめて説 明した日本語の平易な解説書は皆無であった，本書には， 準結晶および近似結晶の多数の電子線回折パターンや高 分解能電子顕微鏡像と, そ机らの解採が与えら机ており。 電子線回折になじみのない読者にも容易に理解できる。 そ の内容は、準結晶の構造は 5 回対称, 10 回対称のカラム 状クラスターや正 20 面体対称クラスターなどの準結晶と 同じ対称性もった原子クラスターが準周期配列した構造 である、という一貫した立場で書かれている点に特徵が ある。

\section{本書は}

第1 章 黄金比の幾何学

第 2 章 準周期格子.

第3 章 回折パターンから見た準結晶

第4 章 高分解能電子顕微鏡像から見た準結晶

第 5 章 2 次元準結晶と近似結晶の構造

第6 章 正 20 面体潐結晶と近似結晶の構造

付録

の構成をとっている.

第 1 章は自然界に普遍に現れる黄金比と多面体の関係 を隼結晶に関連して短くまとめてあり有用である. 第2 章 は準結晶の構造を理解するうえで重要となる準周期格子 について述べられている. 準結晶を高次元の断面として
記述した場合に, 必然的に現れる準結晶特有のフェイゾン (ランダムフェイゾン,リニアーフェイゾン)についての 平易な解説もここで与えられる. 第3 章は種々の準結晶の 電子線回折パターンをとおして、準結晶とはどのような ものであるか. 結晶との違いが示される. 第 4 章は高分解 能電子顕微鏡像とその解釈にあてら机, 格子像と構造像 の違いが説明される，前者は準周期格子に関する知見を， 後者は局所的な原子配列に関する知見を与えること,およ びどのような条件でそのような像が得られるかが説明さ れる. 第 5 章はほかの章に比べてひときわ長い. 著者の力 点がこの章にあることが何える。ここでは準結晶や近似 結晶の構造像の解釈から得られた, 種々の 2 次元準結晶の 構造モデルが統一された形で解説される. 第 6 章は正 20 面体準結晶の近似結晶の X 線結晶構造解析の結果が詳細 に述べられる，その近似結晶中に存在するクラスター構 造に基づき, 実際の正 20 面体準結晶の構造が考察される.

このような解説書としては珍しく、多くの原著論文が 引用されている，序文にも述べられているように，ほとん どの例が著者の研究室でなされた研究成果に基づいてい る.それゆえ，それらの文献は偏ったものであることはし かたがない．また、第2 章で取り上げられた 2 次元準洁期 規則格子は，著者独自のものである。したがって，そ扎に 基づく高分解能電子顕微鏡像の解釈には議論があるであ ろう。進んだ読者にはほかの成書や本書に引用されてい ないほかの文献に適宜あたってみることが必要となる。

しかしながら, 細かい内容は別にして, 全体として読み やすく魅力的で優れた解説書であることにはかわりない． 本文の随所に挿入された，肩のこらない“ティータイム” (蛇足の説明) は本書をより魅力的なものにしている。ま た、ブリタニカ百科事典にも揭載されているという。準結 晶は多重双晶ではないことを世界で最初に明確に示した， 歴史的な Al-Mn 系证 20 面体準結晶の高分解能格子像も 本書に収録されており，必見である. 付録には準結晶の試 料作成法もまとめられており，試料を自作しようという 読者の便宜をはかっている，また，添付されている多面体 の型紙は，実際に多面体を作成して立体構造をつくり，準 結晶構造のイメージを得るのに好都合であろう.

本書によって準結晶の不思議さに触れた読者が自然の 美しさを再認識するとともに，この分野に興味をもって いただければ幸いである。

(物質・材料研究機構 物質研究所 高蒼洋礼) 